Interpretation of the properties of chromatin extracts from mammalian nuclei.

\title{
A.J.Marshall and L.A.Burgoyne
}

School of Biological Sciences, Flinders University of South Australia, Bedford Park, South Australia 5042

Received 24 February 1976

\section{ABSTRACT}

Chromatin from standard preparations of nuclei stabilized by magnesium ions at $0-4^{\circ} \mathrm{C}$ was degraded during the nuclear isolation, and newlysynthesized chromatin was degraded slightly more slowly than the 'older' chromatin. The significance of this observation, and its relation to the interpretation of the properties of nucleoprotein extracts is discussed.

\section{INTRODUCTION}

Chromatin that has been extracted from a mammalian cell with minimal modification is invariably found to exist in one of two states. It is either a suspension of insoluble bodies (nuclei, or nuclear fragments), or a soluble, but intractable, gel.

In the past, preparations of soluble chromatin have generally depended on conversion of the ultra-high molecular weight species in the intractable gel to much lower molecular weight species. This has generally been achieved by various combinations of two different procedures. In one type of procedure, nucleolytic scission of the chromatin is avoided, and the resultant intractable gels are sheared until they have acceptable physical properties ${ }^{1-3}$. The undesirable consequences of this procedure have been discussed by No11, Thomas and Kornberg ${ }^{4}$. In the other type of preparative procedure, nucleolytic scission by exogenous endonuclease is used to lower the average molecular weight of the chromatin ${ }^{5,6}$. Many studies of chromatin however generally start with a nuclear preparation which utilizes calcium or magnesium ions to maintain morphologically intact nuclei, for example references 2 and 7. However, either calcium or magnesium ions in the presence of traces of the other will activate endogenous $\mathrm{Ca}-\mathrm{Mg}$ dependent endonuclease ${ }^{8}$, and the degree of activation is thus both dependent on the levels of the ion in limiting supply, and also on the metabolic state 
of the tissue, since this determines the level of $\mathrm{Ca}-\mathrm{Mg}$ endonuclease activity in the nuclei ${ }^{8}$. Use of low temperatures $\left(0-4^{\circ} \mathrm{C}\right)$ during preparation of nuclei is unlikely to prevent residual endonuclease activity in the presence of $\mathrm{Ca}$ and $\mathrm{Mg}$ ions, and data presented in this paper suggest that during a representative magnesium-stabilised nuclear preparation at $0-4^{\circ} \mathrm{C}$, of several hours duration, such nucleolysis reaches very significant levels.

All these considerations are quite serious enough to warrant considerable caution in the interpretation of any results obtained from chromatin produced in the presence of calcium and/or magnesium ions under poorly-defined conditions.

However, if use of these stabilisation procedures involving divalent cations continues, with consequent complications from nucleolysis, there is a further effect that should be considered, which is the main subject of this paper.

\section{$\underline{\text { METHODS }}$}

Experimental animals. Livers were obtained from approximately 12 week old Hooded Wistar rats.

Preparation of pulse-labelled polyamine-stabilised nuclei (Procedure $[A]$ ). Nuclei were prepared from livers using a modification of the methods of Burgoyne et al. ${ }^{8-11}$. 16 hours after hepatectomy, livers were pulse-labelled with $40 \mu \mathrm{Ci}{ }^{3} \mathrm{H}$-thymidine in $0.5 \mathrm{ml}$ saline solution per liver, administered by intraportal injection, then surgically removed after 10 minutes labelling, and homogenised together in $100 \mathrm{ml}$ of Buffer $\mathrm{A} 1$, which contained $0.34 \mathrm{M}$ sucrose, $2 \mathrm{mM}$ EDTA, and $0.5 \mathrm{mM}$ EGTA in Buffer A. After filtration through gauze, the homogenate was layered onto 0.33 volumes of Buffer $A 2$, which contained $1.37 \mathrm{M}$ sucrose, $1 \mathrm{mM}$ EDTA and $0.3 \mathrm{mM}$ EGTA in Buffer A, centrifuged at $16000 \mathrm{~g}$ for 15 minutes, and the pellet was resuspended in Buffer $A 3$, which contained $2.1 \mathrm{M}$ sucrose, $0.1 \mathrm{M}$ EDTA, and $0.1 \mathrm{M}$ EGTA in Buffer A. This suspension, in Buffer $A 3$, was layered onto Buffer $A 3$, and centrifuged at $75000 \mathrm{~g}$ for 45 minutes. The resultant pellet was resuspended in Buffer A4, which contained $0.34 \mathrm{M}$ sucrose, and $0.1 \mathrm{mM}$ EDTA in Buffer $\mathrm{A}$, and centrifuged at $16000 \mathrm{~g}$ for 15 minutes. The purified nuclear pellet was finally resuspended in Buffer A4. Buffer A contained $60 \mathrm{mM} \mathrm{KCl}, 15 \mathrm{mM} \mathrm{NaCl}, 0.5 \mathrm{mM}$ spermidine, $0.15 \mathrm{mM}$ spermine, and $15 \mathrm{mM} \beta$-mercaptoethanol, in $15 \mathrm{mM} \mathrm{Tris}-\mathrm{HC} 1$ 
buffer $\mathrm{pH}$ 7.4. All procedures were carried out in ice $\left(0-2^{\circ} \mathrm{C}\right)$. The duration of the preparation procedure was approximately $3 \mathrm{hr}$.

Preparation of magnesium-stabilised nuclei (Procedure $[B]$ ). The procedure of Berezney and Coffey ${ }^{7}$ was selected, and was adhered to closely without modification.

Activation of $\mathrm{Ca}-\mathrm{Mg}$ dependent endonuclease. Nuclei prepared in Procedure [A] were incubated in Buffer A4 at $37^{\circ} \mathrm{C}$ with $1 \mathrm{mM} \mathrm{Ca}{ }^{2+}, 10 \mathrm{mM}$ $\mathrm{Mg}^{2+}$ to activate the endogenous $\mathrm{Ca}-\mathrm{Mg}$ dependent endonuclease. After a 3 minute incubation, the nuclease activity was terminated by initiating the DNA extraction procedure.

Extraction of DNA from nuclei. In the procedure for $1 \mathrm{ml}$ of nuclear suspension containing approximately $1-3 \mathrm{mg}$ of DNA, $1 \mathrm{ml}$ of phenol- $\mathrm{CHCl}_{3}-$ sodium dodecyl sulphate mixture $\left(5 \%(\mathrm{w} / \mathrm{v})\right.$ SDS in equal volumes $\mathrm{CHCl}_{3}$ and water-saturated phenol), and $0.25 \mathrm{ml}$ of $0.1 \mathrm{M}$ EDTA, $\mathrm{pH} 7.4$, were added, followed by $1.5 \mathrm{ml}$ of $0.5 \mathrm{M}$ potassium pyrophosphate, and $10 \mu 1$ of $\beta$-mercaptoethanol. This emulsion was shaken for $1 \mathrm{hr}$ at room temperature, and then centrifuged at $13000 \mathrm{~g}$ for 20 minutes, at $11^{\circ} \mathrm{C}$. The lower phase was discarded, and the supernatant re-extracted three times by shaking with $1 \mathrm{ml}$ of phenol- $\mathrm{CHCl}_{3}$-sodium dodecyl sulphate mixture, and then centrifuging at $13000 \mathrm{~g}$ for 20 minutes at $11^{\circ} \mathrm{C}$. The final aqueous phase was dialysed overnight at $4^{\circ} \mathrm{C}$ against $1 \mathrm{mM}$ EDTA $(\mathrm{pH} 7.4)$. The dialysate was concentrated, and then prepared for density gradient centrifugation by dialysis for $24 \mathrm{hr}$ against saline citrate (15 mM sodium citrate, $150 \mathrm{mM} \mathrm{NaCl})$.

Fractionation of DNA. DNA was fractionated by centrifugation on $5 \mathrm{ml}$ linear sucrose gradients $(5-20 \%$ sucrose, containing $15 \mathrm{mM}$ sodium citrate, and $150 \mathrm{mM} \mathrm{NaCl}) . \mathrm{E}_{260}$ and ${ }^{\mathrm{H}}$ activity were determined for each fraction, and approximate molecular weights were determined for DNA using the formula of Burgi and Hershey ${ }^{12}$.

\section{$\underline{\text { RESULTS }}$}

Analysis of DNA from polyamine-stabilised nuclei prepared from fully regenerated liver following fragmentation of chromatin by activation of endogenous Ca-Mg dependent endonuclease. Polyamine-stabilised nuclei were prepared from ${ }^{3} \mathrm{H}$-labelled livers by Procedure [A] except that 
the ${ }^{3} \mathrm{H}$-thymidine was given intraperitoneally and the animals were used two weeks instead of 10 minutes after labelling.

Sucrose density gradient centrifugation of native DNA fragments, generated by activation of $\mathrm{Ca}-\mathrm{Mg}$ dependent endonuclease for 3 minutes in

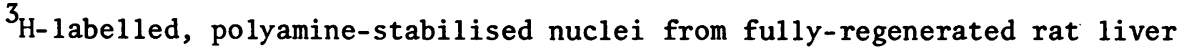
(Fig. 1) resulted in fragments in the range 40-0.5 $\times 10^{6}$ Daltons molecular weight, with a maximum frequency at $2.5 \times 10^{6}$ Daltons. Tritium activity

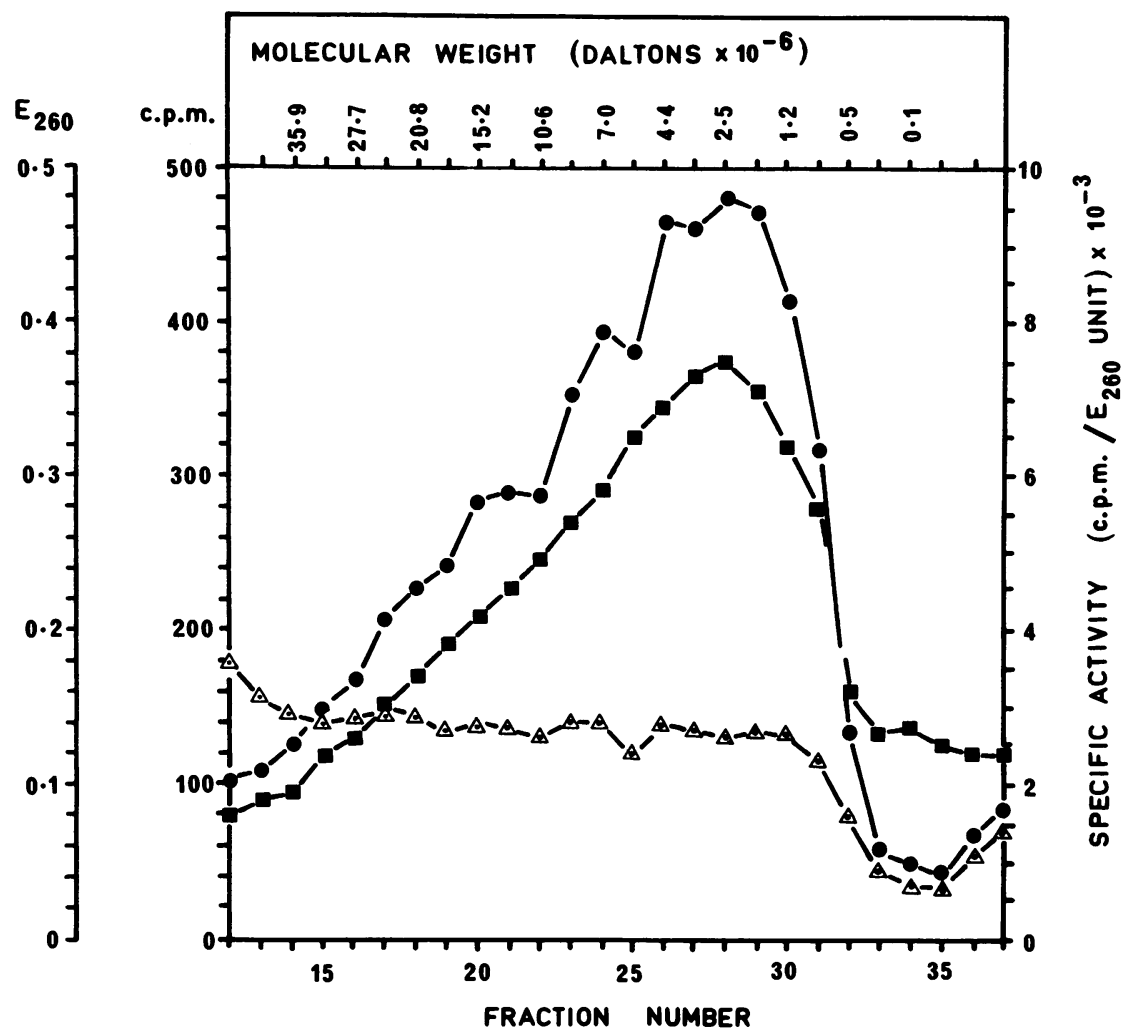

FIGURE 1. SPECIFIC RADIOACTIVITY OF ${ }^{3}$ H-DNA AS A FUNCTION OF MOLECULAR WEIGHT: A CONTROL EXPERIMENT.

Fractionation of DNA from preparations of nuclei from regenerated rat liver, stabilised with polyamines, after controlled activation of $\mathrm{Ca}-\mathrm{Mg}$ dependent endonuclease for 3 minutes. Samples of native DNA (100 $\mu 1$ containing $110 \mu \mathrm{g}$ DNA) were centrifuged on $5-20 \%$ sucrose gradients at $240000 \mathrm{~g}$ (average), for $2.5 \mathrm{~h}$, at $4^{\circ} \mathrm{C}$. $130 \mu \mathrm{l}$ DNA fractions were collected, diluted to $430 \mu 1$ with distilled water, and $E_{260}$ determined. 'Fraction 37 represents the top of the gradient.

Key to symbols: ( $\mathrm{E}_{260} ;{ }^{3} \mathrm{H}$-DNA activity in c.p.m.; $\Delta$ specific radioactivity of $3_{H-D N A}$ in c.p.m./ $/ E_{260}$ unit). 
was shown to reside entirely in DNA over the range of fractions represented in Figs. 1-2, since incubation with DNAase I converted all ${ }^{3} \mathrm{H}$ activity to 5\% trichloroacetic acid-soluble fragments. Although the fractions nearest the bottom of gradients contained a slight trace of DNAase I-resistant ${ }^{3} \mathrm{H}$ activity, which was assumed to be glycogen ${ }^{13}$, this was too low to be a significant factor in the interpretation of profiles of $\mathrm{E}_{260}$ and ${ }^{3} \mathrm{H}$ activity.

The peaks of $\mathrm{E}_{260}$ and ${ }^{3} \mathrm{H}$ activity coincided (Fig. 1), and the level of specific radioactivity of ${ }^{3} \mathrm{H}$-DNA showed no marked increase with increasing distance from the top of the gradient.

Degradation of chromatin in nuclei from regenerating liver.

(a) Analysis of DNA from Mg-stabilised nuclei containing nominally undegraded chromatin. Sucrose density gradient centrifugation of native DNA fragments extracted from $\mathrm{Mg}^{2+}$-stabilised nuclei, but pulse-labelled with $3_{\mathrm{H}}$ as in Procedure [A], showed a single peak of DNA in the molecular weight range of approximately 3-0.02 × $10^{6}$ Daltons, with a maximum at 0.14-0.38 Daltons (Fig. 2). Peaks of $\mathrm{E}_{260}$ and ${ }^{3} \mathrm{H}$ activity again appeared to coincide although a slight tendency was noted in some replicate experiments for the tritium peak to occur at slightly greater values of molecular weight than the $\mathrm{E}_{260}$ maximum. However, the specific radioactivity of ${ }^{3} \mathrm{H}$-DNA showed a clear, and repeatable, tendency to increase with increased distance from the top of the gradient.

(b) Analysis of DNA from polyamine-stabilised nuclei prepared from regenerating liver $16 \mathrm{~h}$ after hepatectomy following fragmentation of chromatin by activation of $\mathrm{Ca}-\mathrm{Mg}$ dependent endonuclease. Short-term digests of polyamine-stabilised nuclei, in which endogenous $\mathrm{Ca}-\mathrm{Mg}$ dependent endonuclease was activated, were conducted as a basis for comparison with the extent of chromatin breakdown incurred during preparation of $\mathrm{Mg}^{2+}$ stabilised nuclei. Comparison between chromatin fragments, and undegraded chromatin was not possible since chromatin in undegraded state formed an intractable gel of molecular weight beyond the resolving capacity of the sucrose gradients. Sucrose density gradient centrifugation of native DNA from polyamine-stabilised nuclei which had been pulse-labelled with ${ }^{3} \mathrm{H} 16 \mathrm{hr}$ after partial hepatectomy, and incubated with $1 \mathrm{mM} \mathrm{Ca}{ }^{2+}$, and $10 \mathrm{mM} \mathrm{Mg}^{2+}$ ions for $2.5,3$ and 4 minutes, showed results similar to those presented in Fig. 2 . Endonuclease activity again generated a single peak of DNA fragments which coincided with a single peak of ${ }^{3} \mathrm{H}$ activity. Values of molecular weight 
for the size-class of DNA fragments of maximum frequency, generated during a 4 minute incubation, were approximately $3 \times 10^{6}$ Daltons, which by comparison with values given in Fig. 2 confirms the extensive breakdown which had occurred during the preparation of nuclei in the presence of $\mathrm{Mg}$ ions. An increase in specific radioactivity of ${ }^{3} \mathrm{H}$-DNA with increasing molecular weight was again observed, similar to that seen in Fig. 2 .

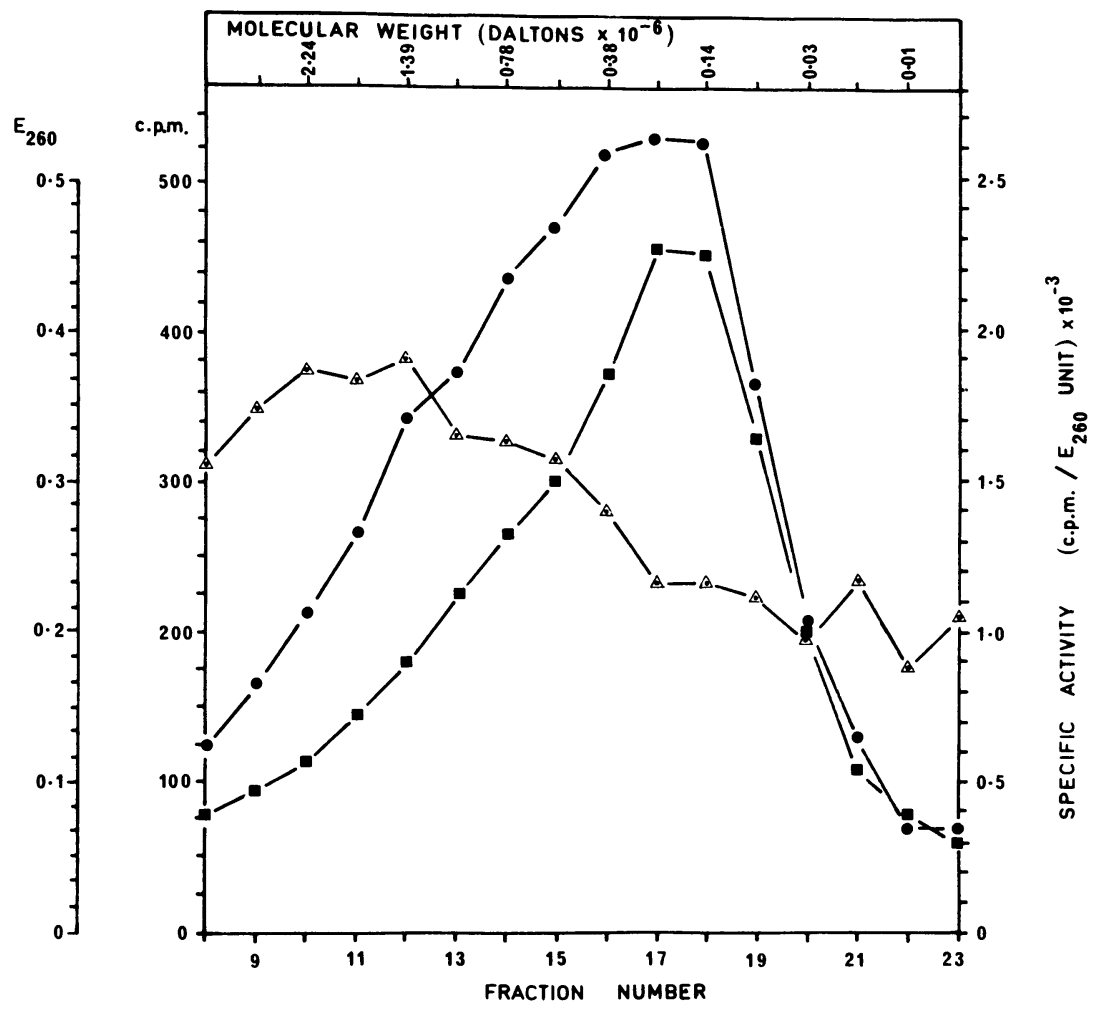

FIGURE 2. SPECIFIC RADIOACTIVITY OF ${ }^{3}$ H-DNA AS A FUNCTION OF MOLECULAR WEIGHT: $\mathrm{Mg}^{2+}-$ STABILISED NUCLEI.

Fractionation of DNA from preparations of nominally undigested nuclei from regenerating rat liver, stabilised with $\mathrm{Mg}^{2+}$ ions. DNA samples $(100 \mu 1$ containing $120 \mu \mathrm{g}$ DNA) were centrifuged on 5-20\% sucrose gradients at $24000 \mathrm{~g}$ (average), for $6 \mathrm{~h}$, at $4^{\circ} \mathrm{C}$. $200 \mu 1 \mathrm{DNA}$ fractions were collected, diluted to $430 \mu 1$ with distilled water, and $E_{260}$ determined.

Key to symbols: ( $\mathrm{E}_{260} ;{ }^{3} \mathrm{H}$-DNA activity in c.p.m.; $\Delta$ specific radioactivity of ${ }^{3} \mathrm{H}-\mathrm{DNA}$ in c.p.m./ $\mathrm{E}_{260}$ unit).

(c) Analysis of DNA from polyamine-stabilised nuclei prepared from regenerating liver using micrococcal nuclease to fragment chromatin. 
Polyamine-stabilised nuclei, pulse-labelled with ${ }^{3} \mathrm{H}$, were incubated with micrococcal nuclease ( 4 units nuclease with $15 \mathrm{mg}$ DNA as nuclei, and $1 \mathrm{mM}$ $\mathrm{Ca}^{2+}$ per $\mathrm{ml}$ of nuclear preparation), at $37^{\circ} \mathrm{C}$ for 2.5 minutes. Native DNA was extracted and fractionated on $5-20 \%$ sucrose density gradients. A single peak of DNA fragments was observed, coinciding with a single peak of ${ }^{3} \mathrm{H}$ activity, and corresponding to an approximate molecular weight of $0.8 \times 10^{6}$ Daltons (Fig. 3). However, the specific radioactivity of the ${ }^{3} \mathrm{H}$-DNA did

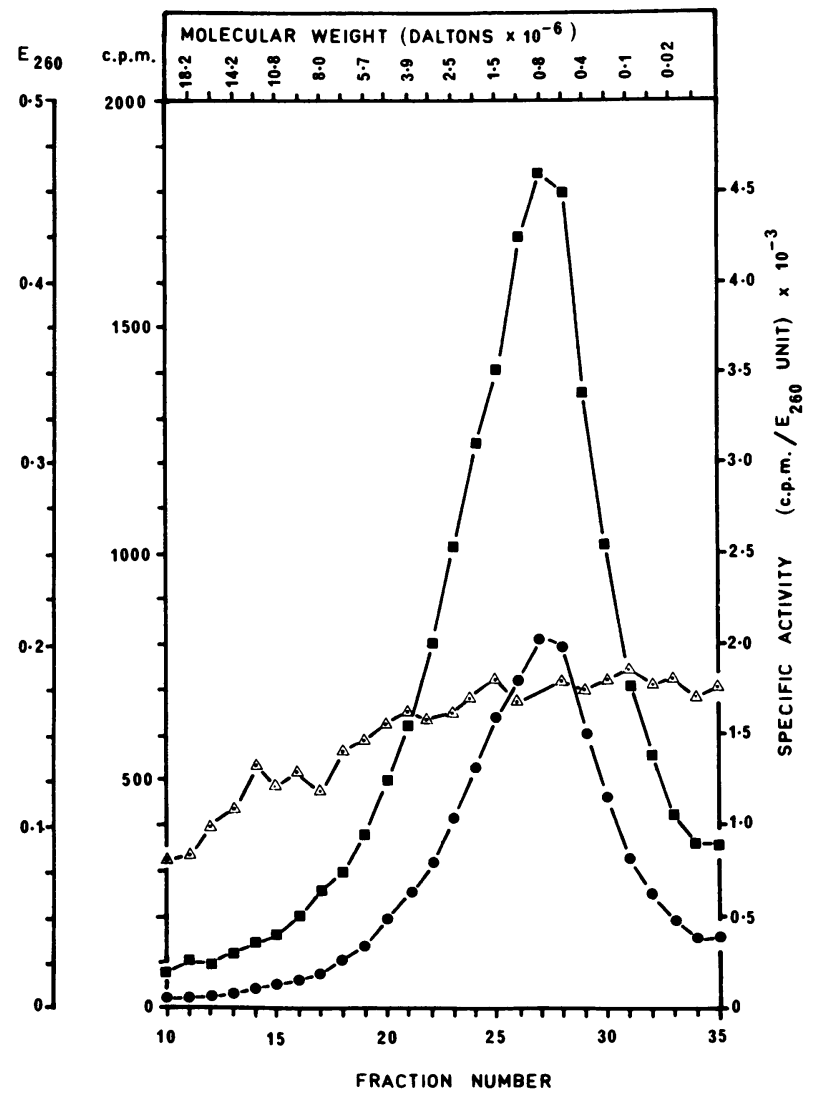

FIGURE 3. SPECIFIC RADIOACTIVITY OF ${ }^{3}$ H-DNA AS A FUNCTION OF MOLECULAR WEIGHT: MICROCOCCAL NUCLEASE DIGEST.

Fractionation of DNA from preparations of nuclei from regenerating rat liver, stabilised with polyamines, after incubation with micrococcal nuclease. DNA samples $(100 \mu 1$ containing $140 \mu \mathrm{g}$ DNA) were centrifuged at $240000 \mathrm{~g}$ for $3.5 \mathrm{~h}$. $130 \mu 1$ DNA fractions were collected, diluted to $430 \mu \mathrm{l}$ with distilled water, and $E_{260}$ determined. Fraction 35 represents the top of the gradient.

Key to symbols: ( $\mathrm{E}_{260} ;{ }^{3} \mathrm{H}$-DNA activity in c.p.m.; $\Delta$ specific radioactivity of $3_{H-D N A}$ in c.p.m. $/ E_{260}$ unit). 
not show the increase with increased values of molecular weight that was observed in Fig. 2. This experiment also acted as a technical control that checks for glycogen labelling in the pulse label experiments.

\section{DISCUSSION}

The degraded nature of native DNA extracted from nuclei stabilised with $\mathrm{Mg}^{2+}$ ions is shown by the low values of molecular weights given in Fig. 2. Comparison of these values with DNA fragments generated by a 3 minute incubation of polyamine-stabilised nuclei (Fig. 1) in the presence of $\mathrm{Ca}^{2+}$ and $\mathrm{Mg}^{2+}$ ions, under defined conditions shows that in $\mathrm{Mg}^{2+}$-stabilised nuclei, the degradation of chromatin during preparation can be 10 times greater. Although this effect is implicit in some earlier work ${ }^{7-11}$, this result, which provides an approximate quantitative comparison between chromatin degradation during $\mathrm{Mg}^{2+}$-stabilised preparations, and controlled nucleolysis, explicitly demonstrates the difficulty in isolation of intact DNA from nuclei prepared in the presence of $\mathrm{Ca}^{2+}$ and $\mathrm{Mg}^{2+}$ ions, and suggests caution in interpretation of effects based on such work. Replicate extractions of DNA from nuclei prepared under $\mathrm{Mg}^{2+}$-stabilised conditions produced variable fragmentation profiles, dependent both on the poorly-defined conditions of endonuclease activation, and on the duration of nucleolysis, which was determined by the length of the preparation procedure.

Moreover, this nucleolysis does not appear to be distributed randomly between 'old' and newly-synthesised DNA.

The relationship between specific radioactivity of ${ }^{3} \mathrm{H}$ pulse-labelled DNA and fragment size of DNA, shows the approximate distribution of nucleolytic cleavage between newly-synthesised and 'older' DNA. The variation in specific radioactivity of ${ }^{3} \mathrm{H}$-DNA as a function of molecular weight of DNA fragments shows two alternative trends in nuclei from regenerating and regenerated liver.

In regenerated liver the level of specific radioactivity showed no marked dependence on size-class of DNA (Fig. 1), but in actively regenerating liver (Fig. 2) the larger fragments showed a clear, and repeatable, tendency to be of higher specific radioactivity.

This effect may be interpreted either in terms of differences in spacing of sites susceptible to endonuclease action between newly-synthesised and 'older' DNA, or in terms of the model favoured here, an effect caused by different levels of active endonuclease between nuclei of non-dividing and 
dividing cells, and the different proportions of mitotic cells in regenerating and fully regenerated liver.

It is suggested that this effect, the increase in specific radioactivity of ${ }^{3} \mathrm{H}$-labelled DNA with increased molecular weight of DNA (Fig. 2) can be explained by the low levels of $\mathrm{Ca}-\mathrm{Mg}$ endonuclease in dividing cells from regenerating liver. This low endonuclease content would cause only low frequency cleavage of newly-synthesised, highly-labelled chromatin. Conversely, in the liver which had regenerated for two weeks, and in which the correlation between high level of ${ }^{3} \mathrm{H}$-labelling of DNA and low endonuclease content had disappeared, the effect is exhibited to a far less marked degree (Fig. 1).

Lack of differentiation between newly-synthesised and 'older' DNA by exogenous micrococcal nuclease, as shown by the relationship between intensity of nucleolysis and level of ${ }^{3} \mathrm{H}$-labelling of DNA in Fig. 3 , further implies that the reduced susceptibility of the newly-synthesised DNA to endogenous endonuclease is apparently dependent on some property of the nuclease, or its distribution between nuclei.

It is possible that this effect might explain such observations as those of Berezney and Coffey ${ }^{7}$ (1975), who suggest that newly-synthesised DNA in regenerating liver is retained by nuclei in preference to 'older' DNA. The data presented in this paper suggest that differential retention of newlysynthesised DNA could be simply due to its slightly larger average molecular weight.

\section{BIBLIOGRAPHY}

1. Rickwood, D., He11, A., and Birnie, G.D., (1973), FEBS Letters, 33, 221-224.

2. David, J., Gordon, J.S., and Rutter, W.J., (1974), Proc. Nat. Acad. Sci. U.S.A., 71, 2808-2812.

3. Markov, G.C., Ivanov, I.G., and Pashev, I.G., (1975), J. Mo1. Biol., 93, 405-413.

4. No11, M., Thomas, J.0., and Kornberg, R.D., (1975), Science, 187, 1203-1206.

5. Rees, A.W., and Kreuger, R.C., (1968), Biochim. Biophys. Acta, 161, 558.

6. Gottesfeld, J.M., Garrard, W.T., Bagi, G., Wilson, R.F., and Bonner, J., (1974), Proc. Nat1. Acad. Sci. U.S.A., 71, 2193.

7. Berezney, R., and Coffey, D.S., (1975), Science, 189, 291-293.

8. Hewish, D.R., and Burgoyne, L.A., (1973), Biochem. Biophys. Res. Commun., $52,475-481$.

9. Burgoyne, L.A., Waqar, M.A., and Atkinson, M.R., (1970), Biochem. Biophys. Res. Commun., 39, 254-259. 
10. Hewish, D.R., and Burgoyne, L.A., (1973), Biochem. Biophys. Res. Commun., $52,504-510$.

11. Burgoyne, L.A., Hewish, D.R., and Mobbs, J., (1974), Biochem. J., 143, 67-72.

12. Burgi, E., and Hershey, A.D., (1963), Biophys. J., 3, 309.

13. Dobson, R.L., and Cooper, M.F., (1971), Biochim. Biophys. Acta, 254, 393-401. 